\title{
Kualitas Pelayanan Obat BPJS di Apotek Rawat Jalan RSUD Kelas B Kabupaten Subang
}

\author{
Komir Bastaman ${ }^{1}$ \\ Fakultas Ilmu Administrasi Universitas Subang \\ komirbastaman60@gmail.com \\ Tony Pathony ${ }^{2}$ \\ Fakultas Ilmu Administrasi Universitas Subang \\ topath12dos@gmail.com
}

\begin{abstract}
Abstrak
Penelitian dan penulisan ini membahas hal-hal yang berkaitan dengan Kualitas Pelayanan Rumah Sakit Umum Daerah Kelas B kabupaten Subang dalam Pelayanan Obat di Apotek Rawat jalan Rumah Sakit Umum Daerah Kelas B kabupaten Subang dalam hubungannya dengan teori menurut Fitzsimmons yaitu sumberdaya, ketepatan,kecepatan, jaminan dan empati. Dalam penelitian ini menggunakan pendekatan kualitatif melalui pengamatan dan observasi, wawancara, studi kepustakaan dan dokumentasi. Sumber data diperoleh dari informan melalui pengamatan dan wawancara secara langsung dan dokumen diperoleh dalam bentuk peraturan-peraturan dan pengolahan data. Hasil penelitian menunjukan bahwa berwujud, kehandalan, daya tanggap, jaminan dan empati belum terlaksana secara optimal. Kualitas Pelayanan Rumah Sakit Umum Daerah Kelas B kabupaten Subang dalam Pelayanan Obat di Apotek Rawat jalan RSUD Kelas B Kabupaten Subang belum berjalan berkulitas. Hal ini dapat terlihat dari masih lambatnya kesigapan tenaga Apoteker dalam menangani pasien sehingga pasien yang harus segera mendapatkan pertolongan dibiarkan menunggu.
\end{abstract}

Kata Kunci: Kualitas, Pelayanan obat

\begin{abstract}
This research and writing discusses matters relating to the Quality of Services in the Class B District Subang District General Hospital in Drug Services at the Outpatient Pharmacy Class $B$ Subang District Regional Hospital in relation to the theory according to Fitzsimmons namely tangible, realibility, responsipness, asurance and empathy. In this study using a qualitative approach through observation and observation, interviews, literature studies and documentation. Sources of data obtained from informants through direct observation and interviews and documents obtained in the form of regulations and data processing. The results
\end{abstract}




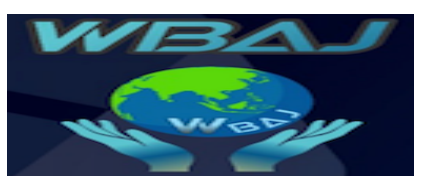

Volume 2 Issue 2, Desember 2020

https://ejournal.unsub.ac.id/index.php/bisnis

showed that tangibility, reliability, responsiveness, assurance and empathy had not been carried out optimally. Service Quality of Subang Regency Class B Regional General Hospital in Drug Services in the Outpatient Pharmacy Class B Subang District Hospital has not yet progressed. This can be seen from the slow alertness of Pharmacists in handling patients so that patients who must immediately get help are left to wait.

Keywords: Quality, drug service

\section{Pendahuluan}

Kualitas pelayanan publik yang disediakan pemerintah masih menimbulkan banyak permasalahan. Pelayanan yang diberikan masih memiliki banyak kelemahan baik dari segi kualitas maupun kuantitas. Seharusnya tidak harus terjadi, mengingat orientasi pelayanan publik bukanlah mencari keuntungan melainkan memberi kepuasan kepada masyarakat. Bentuk pelayan publik beragam yang salah satunya adalah pelayanan kesehatan. Untuk itu lembaga pemberi pelayanan harus sungguhsungguh melaksanakan pelayanan yang baik dan tidak merugikan masyarakat yang menerima pelayanan. Pelayanan Kefarmasian di Rumah Sakit merupakan bagian yang tidak terpisahkan dari sistem pelayanan kesehatan Rumah Sakit yang berorientasi kepada pelayanan pasien, penyediaan Sediaan Farmasi, Alat Kesehatan, dan Bahan Medis Habis Pakai yang bermutu dan terjangkau bagi semua lapisan masyarakat termasuk pelayanan farmasi klinik.

Apoteker khususnya yang bekerja di Rumah Sakit dituntut untuk merealisasikan perluasan paradigma Pelayanan Kefarmasian dari orientasi produk menjadi orientasi pasien. Untuk itu kompetensi Apoteker perlu ditingkatkan secara terus menerus agar perubahan paradigma tersebut dapat diimplementasikan. Apoteker harus dapat memenuhi hak pasien agar terhindar dari hal-hal yang tidak diinginkan termasuk tuntutan hukum. Dengan demikian, para Apoteker Indonesia dapat berkompetisi dan menjadi tuan rumah di negara sendiri. Perkembangan di atas dapat menjadi peluang sekaligus merupakan tantangan bagi Apoteker untuk maju meningkatkan kompetensinya sehingga dapat memberikan Pelayanan Kefarmasian secara komprehensif dan simultan baik yang bersifat manajerial maupun farmasi klinik. Strategi optimalisasi harus ditegakkan dengan cara memanfaatkan Sistem Informasi Rumah Sakit secara maksimal pada fungsi manajemen kefarmasian, sehingga diharapkan dengan model ini akan terjadi efisiensi tenaga dan waktu. Efisiensi yang diperoleh kemudian dimanfaatkan untuk melaksanakan fungsi pelayanan farmasi klinik secara intensif.

Dalam Undang-Undang Nomor 44 Tahun 2009 tentang Rumah Sakit dinyatakan bahwa Rumah Sakit harus memenuhi persyaratan lokasi, bangunan, prasarana, sumber daya manusia, kefarmasian, dan peralatan. Persyaratan kefarmasian harus menjamin ketersediaan Sediaan Farmasi, Alat Kesehatan, dan Bahan Medis Habis Pakai yang bermutu, bermanfaat, aman, dan terjangkau. Untuk meningkatkan pelayanan kesehatan Rumah Sakit Bekerjasama dengan Badan Penyelenggara Jasa Kesehatan (BPJS) diatur dalam UU RI nomor 40 tahun 2004 tentang Sistem Jaminan 
Sosial Nasional. Akan tetapi pelayanan yang diberikan BPJS kepada rumah sakit masih kurang maksimal salah satu contohnya di pelayanan obat BPJS dimana pasien harus mencari ke luar rumah sakit.

Instalasi Farmasi adalah yang bertanggung jawab untuk menyelenggarakan distribusi pelayanan obat, diatur dalam Permenkes Nomor 72 Tahun 2016 Tentang Standar Pelayanan Kefarmasian di Rumah Sakit dan Peraturan Pemerintah Republik Indonesia Nomor 51 Tahun 2009 tentang Pekerjaan Kefarmasian. Dari hasil penjajagan di Rumah Sakit Umum Daerah Kelas B Kabupaten Subang menunjukan adanyan penurunan keperrcayaan terhadap pelayanan yang diberikan oleh RSUD Subang dibuktikan dengan penurunan jumlah kunjungan pasien pada tahun 2017 sebanyak 106.447 orang dan tahun tahun 2018 sebanyak 95.629 orang. Berikut grafik kunjungan pasien tahun 2017 dan 2018:

Kualitas pelayanan obat di Rumah Sakit Umum Daerah Kelas B Kabupten Subang akan sangat bergantung terhadap bagaimanan pengelolaan Instalasi Farmasinya. Instalasi Farmasi di rumah sakit mempunyai tugas cukup berat mengingat bahwa perbekalan farmasi rumah sakit merupakan hal yang kompleks. Material yang dipergunakan cukup banyak, teknologi yang terus berkembang dan otoritas kewenangan medis yang berada dikelompok profesi. Melihat jenis penyakit pasien yang berbeda pasti mempengaruhi jenis obat yang digunakan. Harus diingat bahwa pelayanan perbekalan farmasi berorientasi kepada pasien menuju penggunaan obat secara rasional.Bentuk distribusi pelayanan kefarmasian salah satunya adalah obat BPJS yang harus dilakukan oleh Apoteker dan Tenaga Teknis Kefarmasian (TTK) dibawah pengawasan Apoteker. Pendistribusian obat BPJS sampai kepada pasien BPJS ada beberapa tahapan yang harus ditempuh pertama pasien harus antri pendaftaran untuk pendaftaran peserta BPJS tidak sama dengan pasien umum.

Untuk pasien BPJS harus ada persyaratan yang harus dilengkapi yaitu: Kartu BPJS, KTP, dan Rujukan dari Puskesmas. Setelah beres daftar pasien baru akan mendapatkan pelayanan pemeriksaan medis dari dokter kemudian dokter memberikan resep obat sesuai dengan diagnosis klinis pasien, kemudian pasien menyerahkan resep kepada petugas Farmasi dan kembali pasien harus antri untuk mendapatkan pelayanan obat dan baru kemudian pasien mendapatkan obat.Menurut Kepala Instalasi Farmasi Rumah Sakit Umum Daerah Kelas B Kabupaten Subang dari hasil evaluasi dan kajian tentang Sumber Daya Manusia diketahui bahwa Instalasi Farmasi Rumah Sakit Daerah Kabupaten Subang masih kekurang Tenaga Teknis Kefarmasian (TTK). Jumlah Apoteker sebanyak 13 orang dan TTK sebanyak 26 orang. Tugas TTK adalah untuk membantu Apoteker dalam meberikan pelayanan kefarmasian. Kekurangan TTK ini bisa menyebabkan kualitas pelayanan obat kepada pasien tidak optimal.

Berdasarkan hasil penulisan yang penulis lakukan dapat dilihat dari indicator sebagai berikut:

1. Berdasarkan inforamasi dari pasien yang telah berobat ke Rumah Sakit Daerah Kabupaten Subang bahwa Pelayanan obat untuk pasien BPJS harus antri lama antara 60 menit sampai 120 menit. Sedangkan SOP pelayanan obat adalah 30 menit utuk obat non racik dan 60 menit untuk obat racik (sumber dari SOP Instalasi Farmasi Rumah Sakit Umum Daerah Kelas B) 
2. Ketersedian obat belum 100 persen terpenuhi yaitu dengan banyaknya copy resep yang dikeluarkan baik itu oleh Apotek rawat inap maupun oleh apotek rawat jalan. Sehingga pasien harus membeli obat di luar Apotek Rumah Sakit

3. Menurut kepala Instalasi Farmasi RSUD Kelas B Kabupatn Subang bahwa masih kekurang 4 apoteker dan 10 tenga teknis kefarmasian (TTK).

\section{Kerangka Teori}

Paimin Napitupulu dalam bukunya yang berjudul Pelayanan Publik dan Customer Satisfaction Napitupulu, (2007:164) mengartikan pelayanan sebagai berikut: "Serangkaian kegiatan atau proses pemenuhan kebutuhan orang lain secara lebih memuaskan berupa produk jasa dengan sejumlah ciri seperti tidak berwujud, cepat hilang, lebih dapat dirasakan daripada memiliki, dan pelanggan lebih dapat berpartisipasi aktif dalam proses mengkonsumsi jasa tersebut". Pelayanan adalah suatu urutan kegiatan dalam rangka pemenuhan kebutuhan masyarakat. Pelayanan tidak memiliki wujud melainkan pelayanan cepat hilang, dan dapat dirasakan. Pelayanan umum dalam kehidupan pemerintah banyak sekali jenisnya, Fitzsimmons dalam Ibrahim (2008:4). menjabarkan pelayanan dapat dibedakan, antara lain: "Elemen struktural dan elemen manajerial. Dalam konsep elemen struktural meliputi aplikasi rancangan fasilitasnya, lokasi pelayanannya, dan kapasitas perencanaannya. Elemen manajerial meliputi penemuan model pelayanan yang tepat, kualitas, kapasitas pengelolaannya, mengerti tuntutan dan tantangannya, serta kelengkapan informasinya".

Perbedaan jenis pelayanan umum dapat dilihat dari kebutuhan masyarakat yang meliputi kebutuhan makanan, pakaian, perumahan, kesehatan, keamanan, transportasi, pendidikan, dan sebagainya. Dilihat dari kegiatan pemerintah yang harus memberikan pelayanan dapat dibedakan berdasarkan kekhususan yang mengaitkan perbedaan jenis pelayanan yang diberikan. Sebelum menguraikan pengertian kualitas pelayanan penulis akan menguraikan mengenai pengertian pelayanan menurut para ahli, yaitu George S.Odiorne dalam Moenir (2001:163) mengemukakan bahwa: "pelayanan merupakan sebuah aktivitas, dan aktivitas adalah usaha dan peroses dengan menggunakan keahlian dan teknik yang dapat mengubah bahan menjadi sesuatu baik dalam wujud barang ataupun jasa yang bermanfaat". Menurut Kotler dalam Wasistiono (2002:53) memberikan definisi bahwa: "pelayanan adalah seperangkat tindakan/kineja dimana satu pihak dapat ditawarkan kepada pihak lain, kuhususnya yang bersifat nyata dan tidak berkaitan dengan masalah kepemilikan. Peroduk berupa barang-barang fisik atau jasa". Dari pengertian di atas penulis menyimpulkan bahwa pelayanan merupakan kegiatan pemberian jasa atau barang oleh pihak satu kepada pihak lain. Lukman (2009:14) berpendapat bahwa: "pelayanan adalah suatu kegiatan atau urutan kegiatan yang terjadi dalam interaksi langsung antara seseorang dengan orang lain atau mesin secara fisik dan menyediakan kepuasan".

Sedangkan Gronroos dalam Ratminto dan Atik Septi Winarsih, (2008:1) mengumumkan pendapat sebagai berikut: "pelayanan adalah suatu aktivitas atau serangkaian aktivitas yang bersifat tidak kasat mata (tidak dapat diraba) yang terjadi 
akibat interaksi antara konsumen dengan kariyawan atau hal-hal yang disediakan oleh perusahaan pemberi pelayanan yang dimaksud untuk memecahkan permasalahan konsumen/pelanggan". Dari berbagai pengertian di atas penulis menyimpulkan bahwa pelayanan merupakan kegiatan pemberian jasa atau barang kepada masyarakat umum yang dilakukan sebagai pemberi pelayanan.

\section{Konsep Kualitas Pelayanan}

Kualitas pada dasarnya terkait dengan pelayanan terbaik, yaitu suatu sikap atau cara kerja aparat dalam melayani masyarakat secara memuaskan. Lukman (2009:11) mengumumkan bahwa " kualitas adalah janji pelayanan oleh aparat kepada masyarakat sebagai pihak yang dilayani agar mereka merasa puas dan diuntungkan" sedangkan Triguno (2007:76) mengartikan bahwa: Kualitas adalah setandarisasi yang harus dicapai oleh seorang atau kelompok atau lembaga atau organisasi mengenai kualitas sumber daya manusia, kulitas cara kerja,peroses yang dihasilkan kerja atau peroduk yang berupa barang dan jasa. Berkualitas mempunyai arti memberi kepuasaan kepada yang dilayani, baik internal maupun ekternal, dalam arti optimal pemenuhan atas tuntutan pelanggan atau masyarakat".

Salah satu unsur penting dari mutu kehidupan dalam pembangunan Nasional untuk mewujudkan masyarakat seutuhnya adalah kualitas . kualitas bertujuan untuk memberikan gambaran atas hasil yang dicapai untuk memuaskan masyarakat. Istilah kualitas memang tidak terlepas dari manajemen kualitas yang mempelajari setiap area dari manajemen dan perencanaan peroduk dan fasilitas, sampai penjadwalan dan monitoring hasil. Kualitas merupakan bagian dari semua fungsi usaha yang lain (Pemasaran,SDM,keuangan dan lain lain) selain itu kualitas memerlukan suatu peroses perbaikan yang terus menerus (continuous improvement process) yang dapat diukur, baik secara individu,organisasi, korporasi dan tujuan kerja. dukungan manajeman,kariyawan dan pemerintah untuk perbaikan kualitas adalah penting bagi kemampuan berkopentisi secara efektif di pasar global.

Garvin (lovelock,2004:78) pengertian kualitas perspektif adalah sebagai berikut:

1. Trancedental approach, yang menganggap kualitas sebagai innate excellence, yaitu kualitas dapat dirasakan tetapi sulit untuk didefinisikan atau dioprasionalkan.

2. Product basic approach, yang menganggap bahwa kualitas merupakan karakteristik atau atribut yang dapat di ukur.

3. User basic approach, yang memandang kualitas tergantung kepada orang yang memandangnya, sehingga produk yang bisa memuaskan seseorang merupakan produk yang mempunyai kualitas yang lebih tinggi.

4. Manufacturing based approach, yang memandang bahwa kualitas sebagai kesesuaian dengan persaratan (conformance to requirements). dalam sektor jasa,dapat dikatakan bahwa kualitasnya bersipat (operations driven).

5. Velue based approach, yang memandang kualitas dari segi nilai dan harga dengan mempertimbangkan trade off antara kinerja dengan harga. kualitas di definisikan sebagai offordable excellence.

Dalam kenyataanya kualitas adalah konsep yang cukup sulit untuk dipahami dan disepakati. Kualitas mempunyai beragam interperentasi, tidak dapat didefinisikan secara tunggal dan sangat tergantung pada konteksnya. Konsep kualitas secara luas tidak hanya menekankan pada aspek hasil tetapi juga kualitas manusia dan kualitas 
perosesnya, kualitas bukan hanya mencangkup peroduk dan jasa tetapi juga meliputi peroses, lingkungan dan manusia. Kualitas pelayanan akan berhubungan erat dengan hubungan langsung antara memberi pelayanan dengan masyarakat baik secara individu maupun secara organisasi. Menurut Lukman (2009:14) mendefinisikan kualitas pelayanan yaitu : "Kualitas pelayanan adalah pelayanan yang diberikan kepada pelanggan sesuai setandar yang telah dibekukan sebagai pedoman dalam pemberian pelayanan. setandar pelayanan adalah ukuran yang telah ditentukan sebagai suatu pembekuan yang baik".

Sedangkan Wyckot dalam Tjiptono (2006:59) mendefinisikan kualitas pelayanan yaitu:"sebagai tingkat keungglan yang diharapkan dan pengendalian atas tingkat keunggulan tersebut untuk memenuhi keinginan pelanggan". Dari kedua pendapat tersebut diketahui bahwa kualitas pelayanan merupakan pemberian pelayanan sesuai setandar pelayanan atau pedomana yang menjadi ukuran untuk mencapai pelayanan yang baik. Gasperz ( 2008:18) mendefinisikan bahwa kualitas mengacu pada pengertian pokok sebagai berikut: Kualitas terdiri atas sejumlah keistimewaan peroduk, baik keistimewaan langsung ateraktif yang memenuhi keinginan pelanggan dan memberikan kepuasan atas penggunaan produk; Kualitas terdiri atas segala sesuatu yang bebas dari kekurangan atau kerusakan.

Berdasarkan pendapat tersebut penulis menyimpulkan bahwa kualitas adalah suatu yang mampu memenuhi keinginan pelanggan disertai peroduk yang bebas dari kekurangan atau kerusakan. Denhardt dan Denhardt (2003:61) faktor untuk mengukur kualitas pelayanan yaitu:

1. Kemudahan (Convenience) yaitu ukuran tingkat dimana pelayanan yang diberikan mudah didapat oleh masyarakat.

2. Keamanan (Security) yaitu ukuran tingkat dimanan pelayanan yang telah disediakan oleh pemerintah membuat masyarakat menjadi aman.

3. Keandalan (Reliability) yaitu tingkat dimana pelayanan pemerintah disediakan secara benar dan tepat waktu.

4. Perhatian kepada orang (Personal attentions) yaitu ukuran dimana tingka dimana aparat pelayanan menyediakan informasi kepada mesyarakat dan bekerja dengan masyarakat untuk memenuhi kebutuhan-kebutuhanya.

5. Pendekatan pemecahan masalah (Peroblem solving approach) yaitu ukuran dimana aparatur pelayanan senantiasa bersedia memberikan pemecahan masalah terhadap kahsus-kasus yang dihadapi oleh masyarakat yang berkaitan tentang layanan yang diminta

6. Keadilan (fairnes) yaitu ukuran tingkat dimana masyarakat percaya bahwa pelayanan pemeritah disediakan sama pada semua orang.

7. Tanggug jawab keuangan (Fiscal responsibility) yaitu ukuran tingkat dimana masyarakat percaya bahwa pemerintah menyediakan pelayanan sebagai mestinya yang menggunakan uang rakyat secara tanggung jawab.

8. Pengaruh masyarakat (citizen influence) yaitu ukuran tinggi dimana masyarakat percaya bahwa mereka dapat mempengaruhi kualitas pelayanan yang diterima dari pemerintah.

Yang dikemukakan diatas tentang kualitas pelayanan cukup lengkap untuk menganalisis kualitas pelayanan publik tetapi disini penulis beranggapan bahawa teori tersebut lebih cocok digunang oleh penelitian yang menggunakan metode 


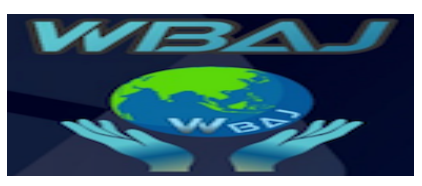

penelitan kuantitatif karena ada dimensi pengaruh masyarakat sedangkan penulis menggunakan metode kualitatif. Maka penulis lebih memeilih Fitzsimmons dan Fitzsimmons dalam Sinambela (2011:7) faktor utama mengukur kualitas pelayanan yaitu:

1. Tengibles yaitu penyedian sumber daya manusia dan sumber daya lainya.

2. Reliability yaitu pemberian pelayanan yang tepat dan benar.

3. Responsiveness yaitu adanya keinginan untuk memberikan pelayanan dengan cepat.

4. Assurance yaitu tingkat perhatian terhadap etika dan moral dalam memberikan pelayanan.

5. Emphaty yaitu tingkat kemauan untuk mengetahui keinginan dan kebutuhan konsumen/masyarakat.

Adapun Kualitas diartikan sebagai tingkat baik atau buruknya sesuatu atau pribadi yang baik dalam bentuk tingkah laku seseorang yang baik yang dapat dijadikan teladan dalam hidup masyarakat dan bernegara disertai suatu konsep yang ideal yang memenuhui kesempurnaan baik tentang peroduk atau tindakan yang mampu memuaskan orang lain yang menjadi penggunanya.

Dari berbagai factor yang mempengaruhi kualitas pelayanan publik, factor manusia dan system merupakan factor yang sangat menentukan. Kualitas juga dapat diartikan sebagai kesesuaian dengan persaratan, kesesuaian pihak pemakai atau bebas dari kerusakan/cacat. Untuk itu kualitas pelayanan adalah suatu kegiatan pelayanan yang diberikan kepada pelanggan sesuai dengan perinsip: lebih mudah lebih baik, cepat, tepat dan akurat sesuai dengan harapan pelanggan. Kualitas merupakan pelayanan yang diberikan kepada pelanggan sesuai dengan setandar pelayanan yang telah dibekukan seebagai pedoman dalam pemberi pelayaan. Setandar pelayanan adalah ukuran yang telah ditentukan sebagai suatu pembekuan pelayanan yang baik.

\section{Metode Penelitian}

Penelitian ini mengunakan metode kualitatif dengan pendekatan deskriptif. Dengan pertimbangkan karena tujuan penelitian yang akan dicapai dan karakteristik kondisi masalah yang ada di lapangan. Hal ini sesuai dengan Creswell (2010:4) penelitian kualitatif merupakan metode-metode untuk mengeksplorasi dan memahami makna yang oleh sejumlah individu atau sekelompok orang dianggap berasal dari masalah sosial atau kemanusiaan. Peroses penelitian ini melibatkan upaya-upaya penting seperti mengajukan pertanyaan-pertanyaan dan prosedur-prosedur mengumpulkan data sepesifik dari partisipasi, menganalisis data secara induktif melalui tema-tema yang khusus ke tema-tema yang umum dan menafsirkan makna dari data. Metode kualitatif ini juga dapat dikatakan berbasis pada informasi/kenyataan yang terjadi di lapangan. 


\section{Hasil dan Pembahasan}

\section{Gambaran Umum Objek Penelitian}

Instalasi Farmasi adalah unit pelaksana fungsional yang menyelenggarakan seluruh kegiatan pelayanan kefarmasian di Rumah Sakit. Kefarmasian adalah suatu pelayanan langsung dan bertanggung jawab kepada pasien yang berkaitan dengan sediaan farmasi dengan maksud mencapai hasil yang pasti untuk meningkatkan mutu kehidupan pasien. Standar pelayanan kefarmasian adalah tolok ukur yang dipergunakan sebagai pedoman bagi tenaga kefarmasian dalam menyelenggarakan pelayanan kefarmasian.

Pelayanan Kefarmasian di Rumah Sakit meliputi 2 (dua) kegiatan, yaitu kegiatan yang bersifat manajerial berupa pengelolaan Sediaan Farmasi, Alat Kesehatan, dan Bahan Medis Habis Pakai dan kegiatan pelayanan farmasi klinik. Kegiatan tersebut harus didukung oleh sumber daya manusia, sarana, dan peralatan. Apoteker dalam melaksanakan kegiatan Pelayanan Kefarmasian tersebut juga harus mempertimbangkan faktor resiko yang terjadi yang disebut dengan manajemen risiko. Tugas instalasi famasi meliputi:

1. Menyelenggarakan, mengkoordinasikan, mengatur dan mengawasi seluruh kegiatan Pelayanan Kefarmasian yang optimal dan profesional serta sesuai prosedur dan etik profesi.

2. Melaksanakan pengelolaan Sediaan Farmasi, Alat Kesehatan, dan Bahan Medis Habis Pakai yang efektif, aman, bermutu dan efisien.

3. Melaksanakan pengkajian dan pemantauan penggunaan Sediaan Farmasi, Alat Kesehatan, dan Bahan Medis Habis Pakai guna memaksimalkan efek terapi dan keamanan serta meminimalkan risiko.

4. Melaksanakan Komunikasi, Edukasi dan Informasi (KIE) serta memberikan rekomendasi kepada dokter, perawat dan pasien.

5. Berperan aktif dalam Komite/Tim Farmasi dan Terapi.

6. Melaksanakan pendidikan dan pelatihan serta pengembangan Pelayanan Kefarmasian.

7. Memfasilitasi dan mendorong tersusunnya standar pengobatan dan formularium Rumah Sakit.

Pelayanan Kefarmasian di Rumah Sakit merupakan bagian yang tidak terpisahkan dari sistem pelayanan kesehatan Rumah Sakit yang berorientasi kepada pelayanan pasien, penyediaan Sediaan Farmasi, Alat Kesehatan, dan Bahan Medis Habis Pakai yang bermutu dan terjangkau bagi semua lapisan masyarakat termasuk pelayanan farmasi klinik. Apoteker khususnya yang bekerja di Rumah Sakit dituntut untuk merealisasikan perluasan paradigma Pelayanan Kefarmasian dari orientasi produk menjadi orientasi pasien. Untuk itu kompetensi Apoteker perlu ditingkatkan secara terus menerus agar perubahan paradigma tersebut dapat diimplementasikan. Apoteker harus dapat memenuhi hak pasien agar terhindar dari hal-hal yang tidak diinginkan termasuk tuntutan hukum. Dengan demikian, para Apoteker Indonesia dapat berkompetisi dan menjadi tuan rumah di negara sendiri.

Perkembangan di atas dapat menjadi peluang sekaligus merupakan tantangan bagi Apoteker untuk maju meningkatkan kompetensinya sehingga dapat memberikan Pelayanan Kefarmasian secara komprehensif dan simultan baik yang bersifat manajerial maupun farmasi klinik. Strategi optimalisasi harus ditegakkan dengan 
cara memanfaatkan Sistem Informasi Rumah Sakit secara maksimal pada fungsi manajemen kefarmasian, sehingga diharapkan dengan model ini akan terjadi efisiensi tenaga dan waktu. Efisiensi yang diperoleh kemudian dimanfaatkan untuk melaksanakan fungsi pelayanan farmasi klinik secara intensif.

Dalam Undang-Undang Nomor 44 Tahun 2009 tentang Rumah Sakit dinyatakan bahwa Rumah Sakit harus memenuhi persyaratan lokasi, bangunan, prasarana, sumber daya manusia, kefarmasian, dan peralatan. Persyaratan kefarmasian harus menjamin ketersediaan Sediaan Farmasi, Alat Kesehatan, dan Bahan Medis Habis Pakai yang bermutu, bermanfaat, aman, dan terjangkau. Selanjutnya dinyatakan bahwa pelayanan Sediaan Farmasi di Rumah Sakit harus mengikuti Standar Pelayanan Kefarmasian yang selanjutnya diamanahkan untuk diatur dengan Peraturan Menteri Kesehatan.

\section{Kualitas Pelayanan Obat BPJS di Apote Rawat Jalan RSUD Kelas B Kabupaten Subang}

Tangibles (sumber daya)

Salah satu kesuksesan sebuah pelayanan akan sangat ditentukan oleh sumber daya yang dimiliki begitu juga dengan kualitas pelayanan obat BPJS di RSUD Subang. Sumber daya manusia sebagai motor atau penggerak dari pelayanan itu sendiri dan sumber daya obat merupakan pokok dari pelayanan obat BPJS ini. Karena itu proses pelayanan obat yang dirasakan oleh masyrakat mulai dari pelayanan yang diberikan oleh petugas dan ketersedian obat akan menentukan kualitas pelayanan obat BPJS apakah berkualitas atau tidak. Target sediaan obat farmasi adalah 100 persen.Berkaitan dengan sumber daya dalam pelayanan obat, hasil wawancara dengan Kepala Intalasi Farmasi RSUD Kelas B Kabupaten Subang menyatakan bahwa: "Menurut analisis jabatan IFRS di RSUD subang masih kekurangan 4 orang apoteker dan 10 orang tenaga teknis kefarmasian (TTK). Ada beberapa fasilitas farmasi yang kurang memadai, diantaranya tempat racik, washtafel dan dispenser. Semua apoteker dan TTK harus memiliki surat tanda registrsi dan sertifikat kompetensi, serta surat izin praktek yang di keluarkan oleh DPMPTSP. SDM kurang, sarana prasarana kurang lengkap. Kontribusi BPJS sangat kurang sedangkan untuk ketersedian obat baru mencapai 65 persen". (Hasil Wawancara tanggal 20 Desember 2019).

Berdasar standar operasional prosedur farmasi mengacu pada Permenkes No 72 tahun 2016 yaitu, Pelayanan kefarmasian harus dilakukan oleh apoteker atau tenga teknis kefarmasian yang sesuai dengan beban kerja. Perhitungan kebutuhan apoteker berdasarkan baban krja pada pelyanan kefarmasian di rawat jalan yang meliputi pelayanan farmasi manajerial dan pelayanan farmasi klinik dengan aktifitas pengakajian resep, penyerahan obat, pelayanan informasi obat, penyerahan obat, konseling idealnya dibutuhkan tenaga apoteker dengan rasio 1 (satu) apoteker untuk 50 pasien. Pada umumnya 1 apoteker dibantu 2 tenaga teknis kefarmasian (TTK). Hal ini sesuai pernyataan dari penanggung jawab apotek rawat jalan RSUD subang yang mengemungkakan bahwa: "Depo farmasi rawat jalan menerima rata-rata 300 lembar resep, menurut perhitungan diatas defo rawat jalan dibutuhkan 6 orang apoteker dan 12 tenga teknis kefarmasian. Sedangkan saat ini apotek rawat jalan hanya ada 3 apoteker dibantu 6 orang tenaga teknis kefarmasian. Intinya apotek rawat jalan masih 
kekuranga tenaga". (Hasil Wawancara tanggal 20 Desember 2019). Hal serupa juga dirasakan oleh pasien di RSUD Kelas B Kabupaten Subang yang menyatakan: "Saya sudah sering berobat di RSUD Kelas B Kabupaten Subang dan sering menerima copi resef karena obat kosong dan harus mencari obat keluar apotek RSUD Subang". Berdasarkan hasil observasi dikatakan bahwa dimensi tangibles (smber daya) masih kurang dikarenakan masih kurangnya SDM dan ketersedian obat serta penunjang lainya yang mengakibatkan kurang berkulitasnya pelayanan obat BPJS di apotek rawat jalan RSUD Subang.

\section{Realibility (tepat dan benar)}

Dalam pemberian layanan obat yang tepat dan benar apoteker khususnya yang bekerja di Rumah Sakit dituntut untuk merealisasikan perluasan paradigma Pelayanan Kefarmasian dari orientasi produk menjadi orientasi pasien. Untuk itu kompetensi Apoteker perlu ditingkatkan secara terus menerus agar perubahan paradigma tersebut dapat diimplementasikan. Apoteker harus dapat memenuhi hak pasien agar terhindar dari hal-hal yang tidak diinginkan termasuk tuntutan hukum. Dengan demikian, para Apoteker Indonesia dapat berkompetisi sehingga dapat bersaing. Pemberian layanan obat yang tepat dan benar akan memberikan rasa aman kepada pasien. Kualitas pelayanan bias dikatakan baik jika tingkat keamananya baik supaya pengguna jasa pelayanan obat merasa aman dan nyaman mengunakan jasa pelayanan. Seperti yang diungkapkan oleh Kepala Intalasi Farmasi RSUD Kelas B Kabupaten Subang berikut ini: "Acuan Pelayanan Obat adalah Standar Operasional Prosedur (SOP), pedoman pelayanan kefarmasian dan kebijakan direktur. Tugas kami meyakinkan petugas apoteker untuk selalu mengacu pada SOP dalam memberikan setiap pelayanan serta melakukan evaluasi capaian kerja setiap sebulan sekali." (Hasil Wawancara tanggal 20 Desember 2019). Mengacu pada standar pelayanan farmasi adalah Pertama dilakukan adalah pengkajian resep yaitu dilakukan untuk menganalisa adanya masalah terkait obat bila ditemukan masalah terkait obat harus dikonusulkan kepada dokter penulis resep, kedua Apoteker harus melakukan pengkajian resep sesuai (1)persyaratan administrasi, (2)persyaratan farmasetik, (3)persyaratan klinis. Pelayanan resep dimulai dari penerimaan, pemerikasaan ketersedian, penyiapan, peracikan, pemeriksaan (Verifikasi), penyerahan disertai pemberian informasi, pada setiap tahap alur pelayanan resep dilakukan upaya pencegahan terjadinya kesalahan pemberian obat (medication error). Hal ini senada dengan yang diungkapkan Pengggungjawab Apotek Rawat Jalan RSUD Kelas B Kabupaten Subang berikut ini: "dalam memberikan pelayanan obat target capaian kami adalah 100\%. yang telah ditetapkan dalam menkes no/29/menkes/sk/II/2008. Hukuman apabila ada medication error adalah lansung mendapat surat peringatan (Hasil Wawancara tanggal 20 Desember 2019). Adapun salah seorang pasien menyatakan bahwa: "petugas sangat teliti dalam memberikan obat kepada kami sehingga selama saya berobat ke rsud subang tidak terjadi salah ngasih obat kepada kami". (Hasil Wawancara tanggal 20 Desember 2019).

Berdasarkan pada hasil observasi penulis, diketahi bahwa reability (tepat dan benar) dirasakan sudah cukup bagus oleh pasien, terlihat dari sangat sedikit sekali salah dalam pemberian obat yang menumbuhkan rasa aman pada diri pasien serta mempercayakan sepenuhnya pemberian pelayanan obat yang diberikan petugas. 


\section{Responsipness (kecepatan)}

Responsipnes (kecepatan) adalah adanya keinginan untuk memberikan pelayanan dengan cepat. Standar pelayanan minimal rumah sakit mrnurut menkes no/29/menkes/sk/II/2008. Indicator pelayanan farmasi meliputi waktu tunggu pelayanan: (a) Obat jadi $\leq 30$ menit, (b) Obat racik $\leq 60$ menit. Hal ini dikarenakan apotek farmasi rawat jalan hanya satu yang menanampung dari semua poliklinik, SDM yang tidak sesuai dengangan jumlah pasien. Sedangkan penerapan kedisiplinan ketepatn waktu kerja dalam memberikan pelayanan obat telah ditetapkan jam kerja pegawai dengan melaksnakan absensi finger print yang berhubunagan dengan tunjangan kinerjanya. Pada umumnya 1 apoteker dibantu 2 tenaga teknis kefarmasian (TTK). Depo farmasi rawat jalan menerima rata-rata 300 lembar resep, menurut perhitungan diatas defo rawat jalan dibutuhkan 6 orang apoteker dan 12 tenga teknis kefarmasian. Sedangkan saat ini apotek rawat jalan hanya ada 3 apoteker dibantu 6 orang tenaga teknis kefarmasian. Ketersedian obat berhubungan dengan pengadaan yaitu kegiatan untuk merelisasikan perencanaan kebutuhan. Pengadaan yang efektif harus menjamin ketersedian jumlah dan waktu yang tepat dengan harga terjangkau dan sesuai dengan standar untuk saat ini ketersedian obat di RSUD subang belum terpenuhi $100 \%$.

Dalam hal ini pengadaan berhubungan juga dengan ketersedian dana, metode pengadaan, pemantauan proses pengadaan dan pembayaran. RSUD Kelas B Kabupaten Subang melaui intalasi farmasi telah merancang prosedur pelayanan obat ini untuk memudahkan para pasien dalam menerima pelayanan obat hal ini sebagaimana yang di ungkapkan oleh Kepala Intalasi Farmasi RSUD Kelas B Kabupaten Subang yang mengungkapkan bahwa:"Dalam rangka kami meningkatkan kecepatan pelayanan obat yaitu dengan cara mengatur layout atau tata letak ruang apotek agar proses pelayanan resep lebih cepat, mengatur pembagian kerja dengan baik. Ada dua acuan dalam kami melakukan pelyanan yaitu pedoman pelayanan kefarmasian dan kebijakan direktur. Selain itu kami juga mengatur layout dan pembagian kerja yang baik." (Hasil Wawancara tanggal 20 Desember 2019). Pelaksanaan SOP kecepatan waktu pelayanan obat adalah standar pelayanan minimal rumah sakit mrnurut menkes no/29/menkes/sk/II/2008. Indicator pelayanan farmasi meliputi waktu tunggu pelayanan: (a) Obat jadi $\leq 30$ menit, (b) Obat racik $\leq$ 60 menit. Karena kekurangan tenaga apoteker dan tenaga teknis kefarmasian di apotek rawat jalan sehingga pelayanan terlambat. Seperti yang diungkapkan Penanggungjawab Apotek Rawat Jalan yang di temui di lokasi penelitian: "Pelayanan sudah dilakukan sesuai denagan SOP tetapi waktu tunggu pelayanan masih diatas standar pelayanan minimal yaitu: (a) Obat jadi masih diatas 30 menit ( 60 menit), (b) Obat racik masih diatas 60 menit ( 80 - 100 menit). Hal ini dikarenakan apotek farmasi rawat jalan hanya satu yang menanampung dari semua poliklinik. Disisni terjadi ketidakseimbangan antara petugas dengan jumlah pasien sehingga pasien harus sedikit lebih lama dalam mendapatkan pelayanan obat dari waktu yang telah ditetapkan. Sedangkan penerapan kedisiplinan ketepatn waktu kerja dalam memberikan pelayanan obat telah diterapkan jam kerja pegawai dengan melaksnakan absensi finger print yang berhubunagan dengan tunjangan kinerjanya." (Hasil Wawancara tanggal 20 Desember 2019). Adapun hasil wawancara dengan salah seorang pasien di RSUD Kelas B Kabupaten Subang sebagi berikut: "Sebenarnya 
pelayanan obat BPJS di RSUD Subang ini masih kurang, kami harus antri cukup lama bisa sampai 2 jam disamping itu obat yang kami dapatkan dalam beberapa kali kami berobat masih ada yang kosong sehingga kami harus mencari diluar. Yang paling jengkel sih itu, kita sudah antri lama ternyata obatnya juga tidak ada." (Hasil Wawancara tanggal 20 Desember 2019). Berdasarkan hasil wawancara dengan informasi tersebut diatas jika diakaitkan dengan dimensi Responsipness (kecepatan) yang bertujuan untuk memberikan pelayanan obat secara cepat, maka bisa dikatakann kecepatan pelayanan obat BPJS belum berkualitas. Adapun hasil observasi penulis, dikaitakan Responsipness (kecepatan) pelayanan yang diberikan Apotek Rawat Jalan masih sangat kurang baik menurut pasien mengatakan antri sangat lama. Hal senada juga dirasakan oleh para petugas di apotek rawat jalan merka mengeluhkan kekurangan tenga tambahan karena ada ketidak seimbangan antara pasien dengan petugas apotek.

\section{Assurance (kepastian)}

Pelayanan kesehatan merupakan segala kegiatan yang dilakukan oleh penyelenggara pelayanan publik sebagi upaya pemenuhan kebutuhan penerima pelayanan kesehtan. RSUD Kelas B Kabupaten Subang melaksanakan pelayanan dengan Tiga bentuk yaiti:

1. Layanan dengan lisan

Dilakukan oleh seluruh petugas apotek karena sesuai dengan motto RSUD Subang yaitu: seyum, sapa, sopan. Petugas juga dituntut untuk mampu memberikan penjelasan kepada pasien yang berkaitan dengan masalah obat

2. Layanan dengan tulisan.

Layanan dengan tulisan melalui tangan sangat efisien terutama dari segi persepan obat karena pembacaan resep dari dokter itu memerlukan keterampilan khusus. Ada beberapa palayanan tulisan yang diberikan apotek rawat jalan antara lain:

a. Layanan berupa petunjuk dan informasi

b. Layanan berupa copi resep obat.

3. Layanan melalui perbuatan

Pada umumnya pelayanan dalam bentuk perbuatan dilakukan oleh pegawai pegawai tingkat menengah kebawah karena itu factor keahlian dan keterampilan pegawai tersebut dalam hal ini serah terima resep dengan obat. Adapun faktor yang mendukung dari layanan obat yaitu:

1. Adanya kesungguhan dalam melakukan pekerjaan

2. Adanya keterampilan khusus dalam pembacaan resep dan pemberian obat

3. Disiplin dalam hal waktu, prosedur, metode yang telah ditentukan

Petugas akan merespon hal-hal yang ditanyakan pasien dan memberikan penjelasan serta pengarahan terkait dengan keluhan tersebut. Hal ini sebagaimana diungkapkan oleh Kepala Intalasi Farmasi RSUD Kelas B Kabupaten Subang yaitu: “Pelayanan petugas apotek kami cukup baik, dengan tekanan yang besar, kami berusaha untuk tetap sopan dan ramah. Evaluasi kinerja setiap bulan dan mengirimkan untuk di ikutsertakan dalam pelatihan komunikasi efektif agar memberikan informasi yang tepat dan benar". (Hasil wawancara tanggal 20 Desember 2019). Bersikap sopan dan ramah dalam pelayanan kefarmaian sangat diutamakan karena pelayanan kefarmasian adalah pelayanan langsung dan bertnaggung jawab kepada pasien, serta 
berkaitan dengan sedian farmasi bertujan untuk meningkatkan kualitas pelayanan obat. Komunikasi efektif kepada masyarakat dengan cara penyampaian pesan yang jelas dan dimengerti sehingga terjadi feedback dan mengasilkan komunikasi dua arah. Bentuk perhatian yang diberikan kepada pasien seperti seyum, sapa dan sopan yang merupakan moto dari RSUD Subang. Hal senada juga diungkapkan oleh Penanggungjawab Apotek Rawat Jalan beliau menambahkan: "Etika dan moral dalam melakukan pelayanan itu sangat penting guna untuk menumbuhkan rasa nyaman kepada pasien. Komunikasi efektif sangat penting penyampaian pesan yang jelas dan dimengerti sehingga terjadi feedback dan mengasilkan komunikasi dua arah. Bentuk perhatian yang diberikan kepada pasien seperti seyum, sapa dan sopan yang merupakan moto dari RSUD Subang." (Hasil Wawancara tanggal 20 Desember 2019) Berdasarkan hasil wawancara penulis dengan informan tersebut di atas penulis menganalisis bahwa hasilnya pelyananan obat BPJS berkenaan dengan assurance belum maksimal, dibuktikan dengan masih banyaknya keluhan dari masyrakat yang berobat ke RSUD Subang. Tapi dari sisi lain petugas apotek juga telah melaksanakan tugas sesui dengan perturan-peraturan yang berlaku dan melaksanakanya dengan sebaik mungkin. Adapun hasil observasi penulis diketahui bahwa mengenai assurance (perhatian etika dan moral) hasilnya belum berkualitas dan dirasakan langsung oleh pasien, terhihat dari ketidakpuasan pasien setelah berobat di rumah sakit subang.

\section{Empaty (kemauan untuk mengetahui keinginan dan kebutuhan pasien)}

Empaty kemauan untuk mengetahui keinginan dan kebutuhan pasie yaitu ukuran dimana petugas pelayanan senantiasa bersedia memberikan pemecahan masalah dan meberikan pelayanan obat sesuai peraturan serta memberikan apa yang menjadi hak pasien. Indicator Empaty kemauan untuk mengetahui keinginan dan kebutuhan pasien petugas Apotek Rawat Jalan RSUD Kelas B Kabupaten Subang cukup baik hal ini dapat dilihat dari kemampuan petugas Apotek Rawat Jalan RSUD Kelas B Kabupaten Subang yang cukup baik dalam memberikan pelayanan kepada para pasien. Pengetahuan para petugas RSUD Kelas B Kabupaten Subang dapat dilihat dari kemampuan petugas dapat menjawab semua kesulitan-kesulitan yang dialami oleh pasien dengan baik dan tetap berpedoman peraturan. Menurut Kepala Instalasi Farmasi RSUD Kelas B Kabupaten Subang, yaitu: “Ada beberapa cara agar memudahkan pelayanan obat diantaranyan dengan menggunakan alat bantu seperti Leaflet atau Dummy. Kemudian dengan cara membuat SOP sebaik mungkin ". (Hasil Wawancara tanggal 20 Desember 2019). Hal sama diungkapkan penanggung jawat di Apotek Rawat Jalan RSUD Kelas B Kabupaten Subang, yaitu: “dengan cara menjelaskan prosedur pelayanan obat. Memberikan pengertian bahan pelayanan obat berbeda dengan dengan pelayanan komoditi lainya yang memerlukan ketelitian karna berhubungan dengan keselamatan pasein. Yang kami lakukan untuk kemudahan dalam dalam menjalankan prosedur pelayanan obat adalah satu menyiapkan sebuah manajemen obat-obat kronis yang memerlukan obat dalam satu bulan. Kedua memberikan pelayanan konseling obat untuk pasien HIV/AIDS dan TB paru".( Hasil Wawancara tanggal 20 Desember 2019). Hal ini sesuai dengan pendapat seorang pasien yang mengungkapkan bahwa: "Dalam pelayanan pemberian obat sudah benar sesuai dengan hak kami akan tetapi kalau dari segi sikap 
pelayanan terhadap pasien yang kami rasakan masih kurang, informasi juga susah karena tempat yang terlalu bising yang membuat tidak nyaman". (Hasil Wawancara tanggal 20 Desember 2019). Berdasarkan hasil wawancara dengan informan berkaitan denga teori Empaty kemauan untuk mengetahui keinginan dan kebutuhan pasien ada banyak yang dilakukan oleh farmasi guna kemudahan dalam pemenuhan kebutuhan pasien. Diantaranya seperti pembuatan SOP sebagai pedoman dalam melaksanakan pelayanan, menggunakan alat bantu seperti Leaflet atau Dummy sebagai sarana informasi, manajemen obat-obat kronis, dan pelayanan konseling bagi pasien HIV/AIDS dan TB paru. Tetapi menurut pasien dalam hal pemenuhan kebutuhan dan keinginan pasien itu masih belum maksimal sperti tempat tunggu yang terlalu ramai, system antri atau tunggu yang belum jelas kadang kita datang awal tapi keduluan sama orang lain, informasi juga masih kurang, sikap petugas dalam melayani pasien memang belum begitu baik pada pasien. Hasil observasi penulis diketahui bahwa kualitas pelayanan obat dalam keinginan pemenuhan kebutuhan pasien masih belum berkualitas. Ini dibuktikan dengan ketidak puasan pasien terhadap pelayanan obat yang diberikan. Petugas dalam melayani pasien memang belum begitu baik, petugas harus lebih sabar lagi dalam melaksanakan pelayanan kepada pasien, selain mereka sebagai penerima layanan ditambah mereka merupakan orang kurang sehat yang yang seharusnya mendapatkan service lebih. Faktor yang menghambat dalam pelayanan obat BPJS di Apotek Rawat Jalan RSUD Kelas B Subang adalah:

1. Jumlah stok obat BPJS tidak mencukupi sehingga pelayanan Obat di Apotek Rawat Jalan RSUD Subang mengalami kesulitan dalam penyediaan obat untuk setiap pasien yang datang berobat.

2. Jumlah tenaga Apoteker dan Tenaga Teknis Kefarmasian (TTK) belum mencukupi untuk memberikan pelayanan Obat kepada Pasien.

3. Ada ketidakseimbangan antara jumalah paseien dengan Sumber daya manusia sehingga terjadi penurunan kualitas pelayan obat BPJS di apotek rawat jalan RSUD Subang.

4. Proses kerjasama antara BPJS dan RSUD Subang belum berjalan maksimal yang dikarenakan ada penunggkan kewajiban pihak BPJS kepada RSUD Subang yang menggangu operasional kerja.

\section{Kesimpulan}

Kualitas pelayanan obat di Apotek Rawat Jalan RSUD Subang belum berkualitas sesuai dengan kualitas pelayanan menurut Fitzsimmons dan Fitzsimmons dalam Sinambela (2011:7) dengan uraian sebagai berikut:

1. Dimensi tangibles (smber daya) masih kurang dikarenakan masih kekurangan apoteker, tenaga teknis kefarmasian dan ketersedian obat belum terpenuhi seratus persen serta penunjang lainya. Yang mengakibatkan kurang berkulitasnya pelayanan obat BPJS di apotek rawat jalan RSUD Subang.

2. Reliability (ketepatan) pemberian layanan obat yang tepat dan benar yang diberikan apotek rawat jalan sudah sangat baik bisa dikatakan dimensi ini paling unggul diataran dimensi-dimensi kualitas pelayanan yang lain. Hal ini karena 
ditangani oleh ahli-ahli dibidangnya dan juga ada sanksi yang sangat berat apabila ada human error dalam pembrian obat.

3. Responsipness (kecepatan) pelayanan yang diberikan Apotek Rawat Jalan masih sangat kurang. Menurut pasien antri pelayanan obat sangat lama yaitu bisa sampai dua jam lebih ditambah obat juga sering kosong. Hal serupa juga dirasakan oleh petugas di apotek rawat jalan merka mengeluhkan kekurangan tenaga tambahan karena ada ketidak seimbangan antara pasien dengan petugas apotek.

4. Assurance (etika dan moral) merupakan kualitas pelayanan yang paling dasar yaitu pelakasanaa pelayanan harus ramah dan sopan agar memberikan rasa nyaman terhadap pasien. Harapan pasien adalah ketika berobat mereka disambut dengan ramah dan sopn serta tidak dibeda-bedakan satu sama lain. Dimensi assurance ini juga masih kurang.

5. Pembuatan SOP sebagai pedoman dalam melaksanakan pelayanan, menggunakan alat bantu seperti Leaflet atau Dummy sebagai sarana informasi, manajemen obat-obat kronis, dan pelayanan konseling. Tetapi menurut pasien dalam hal pemenuhan kebutuhan dan keinginan pasien itu masih belum maksimal sperti tempat tunggu yang masih kurang, system antri atau tunggu yang belum jelas kadang kita datang awal tapi keduluan sama orang lain, informasi juga masih kurang, sikap petugas dalam melayani pasien memang belum begitu baik pada pasien. Sedangkan yang diiinginkan dan dibutuhkan oleh masyarakat ketika berobat adalah mereka dilayani dengan cepat dan baik, obat tersedia semua, petugas ramah dalam mmberikan pelayanan.

\section{Referensi}

Creswell, John W. 2010. Research Design Pendekatan Kualitatif, Kuantitatif dan Mixed. Yogyakarta. Pustaka Pelajar.

Denhard. 2003. Pengukuran Kualitas Pelayanan: Bandung: CV Pustaka Setia.

Fakhrurrozie, Muhammad. 2004. Konsep Daasar Puskesmas. Bandung: Alfabeta.

Gasperz. 2008. Manajemen Pelayanan Publik. Jakarta: PT Raja Grafindo Persada.

Lukman. 2009. Kinerja Pelayanan Publik. Jakarta: Salemba Empat.

Lovelock. 2004. Asas-asas Manajemen Pelayanan. Bandung: Alfabeta.

Moenir. 2001. Penilaian Kinerja Organisasi Pelayanan Publik. Yogyakarta: Fisipol UGM.

Moleong, Lexy, J, MA, 2005. Metode Penelitian Kualitatif. Bandung: PT. Remaja Rosdakarya.

Nazir, 2005. Metode Penelitian Kualitatif. Jakarta: PT Raja Grafindo Persada.

Notoatmodjo. 2003. Pengertian Pelayanan Kesehatan Masyarakat. Yogyakarta: Graha Ilmu.

Pasolong, Herbani. 2008. Pengertian Pelayanan Publik. Bandung: PT Refika Aditama. 


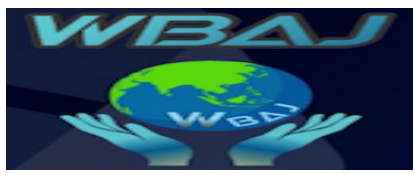

Volume 2 Issue 2, Desember 2020

https://ejournal.unsub.ac.id/index.php/bisnis

Simbolon, Hotman. 2009. Statistika. Yogyakarta: Graha Ilmu.

Sinambela, Lijan Poltak. Dkk 2011, Reformasi Pelayanan Publik, Jakarata: Bumi Aksara.

Singarimbun, Masri. 1995. Metode Penelitian. Jakarta: LP3ES.

Sugiyono. 2010. Metode Penelitian Publik. Bandung: Alfabeta.

Suiudi, Achmad. 2004. Kebijakan Dasar Puskesmas. Bandung: Alfabeta.

Tjiptono. 2006. Kualitas Pelayanan. Jakarta: PT Bumi Aksara.

Triguno. 2007. Manajemen Pelayanan, Teori dan Aplikasi. Yogyakarta: Pustaka Pelajar.

Winarsih, Atik Septi. 2008. Pengukuran Kinerja Sektor Publik. Jakarta: PT Gramedia Widiasarana Indonesia.

Wasistiono. 2002. Manajemen Kinerja Sektor Publik, Edisi I, Yogyakarta: PT BPFE. 